\title{
PENGARUH MOTIVASI BELAJAR DAN KEPERCAYAAN DIRI SISWA TERHADAP PRESTASI BELAJAR
}

\author{
Noni Rozaini ${ }^{1{ }^{*}}$, Sandra Dwi Anti ${ }^{2)}$ \\ 1) Fakultas Ekonomi, Universitas Negeri Medan \\ 2) Alumni Fakultas Ekonomi, Universitas Negeri Medan \\ *Penulis korespondensi: nonirozaini@gmail.com
}

\begin{abstract}
Masalah dalam penelitian ini adalah apakah terdapat pengaruh motivasi belajar dan kepercayaan diri siswa terhadap prestasi belajar ekonomi siswa kelas XI SMA Swasta Raksana Medan Tahun Pelajaran 2015/2016. Penelitian ini dilaksanakan di SMA Swasta Raksana Medan yang beralamat di Jln. Gajah Mada No.20.populasi dalam penelitian ini adalah seluruh siswa kelas XI IPS SMA Swasta Raksana Medan Tahun Pelajaran 2015/2016. Teknik pengambilan sampel yang digunakan dalam penelitian ini adalah total sampling yaitu seluruh bagian dari populasi yang berjumlah 89 orang, dan instrumen yang digunakan untuk mengukur motivasi belajar dan kepercayaan diri berupa angket. Hasil analisi regresi linear berganda diperoleh persamaan garis linear $\mathrm{Y}=28.013+0,234 \mathrm{X} 1+0,458 \mathrm{X} 2$. Teknik analisis data yang digunakan adalah dengan uji t pada taraf signifikan alpha 5\% hasil yang diperoleh menunjukkan motivasi belajar berpengaruh secara signifikan terhadap prestasi belajar dimana nilai thitung>ttabel $(2,151>1,662)$.Dan kepercayaan diri berpengaruh sacara signifikan terhadap prestasi belajar thitung >ttabel $(3,337>1,662)$. Hasil yang diperoleh dari uji $\mathrm{F}$ menunjukkan bahwa variabel motivasi belajar dan kepercayaan diri siswa berpengaruh positif dan signifikan terhadap prestasi belajar ekonomi siswa kelas XI IPS SMA Swasta Raksana Medan dengan nilai Fhitung>Ftabel $(21,783>3,10)$. Berdasarkan hasil penelitian dapat disimpulkan bahwa motivasi belajar dan kepercayaan diri siswa berpengaruh terhadap prestasi belajar ekonomi siswa kelas XI IPS SMA Swasta Raksana Medan.
\end{abstract}

Keyword: motivasi belajar, kepercayaan diri,, dan prestasi belajar ekonomi siswa. 


\section{PENDAHULUAN}

Pendidikan merupakan suatu aspek kehidupan yang sangat mendasar bagi pembangunan suatu negara. Pendidikan adalah suatu proses pengubahan sikap dan tata laku seseorang yang diusahakan untuk mendewasakan manusia melalui pengajaran dan pelatihan. Dalam proses pendidikan, pembelajaran merupakan sesuatu yang harus ditempuh seseorang untuk mengembangkan potensi yang dimiliki siswa agar mampu mencapai kualifikasi dan kompetensi yang ditetapkan. Namun, salah satu masalah yang dihadapi didunia pendidikan adalah masalah lemahnya proses pembelajaran.

Sumber daya manusia dapat terwujud dengan optimal sesuai dengan harapan melalui pendidikan, karena dengan pendidikan siswa belajar berbagai hal tentang ilmu pengetahuan.Sehingga dengan belajar diharapkan siswa yang nantinya merupakan generai penerus bangsa tumbuh dan berkembang menjadi manusia terampil, potensial, dan berkualitas.

Pada saat ini banyak keluhan baik dari orang tua maupun guru mengenai rendahnya kemauan belajar. Kemauan belajar yang rendah akan menurunkan prestasi belajar siswa. Hal tersebut kurang membantu siswa dimasa depan melihat banyaknya persaingan dan tantangan dalam kehidupan.

Pada umumnya proses belajar seseorang dapat dikatakan berprestasi dicapai apabila hasil belajarnya mencapai kriteria ketuntasan minimal (KKM) sesuai yang telah ditetapkan sekolah. Salah satu faktor yang mempengaruhi proses pencapaian prestasi belajar ini adalah tergantung pada faktor kondisi individu siswa itu sendiri. Salah satu bentuk kondisi siswa itu berupa bagaimana cara siswa tersebut memotivasi dirinya sendiri untuk giat belajar.

Siswa belajar karena didorong oleh kekuatan mentalnya.Kekutan mental itu berupa keinginan, perhatian, kemauan, atau cita-cita.Kekuatan mental tersebut dapat tergolong rendah atau tinggi.Kekuatan mental
JURNAL NIAGAWAN Vol 6 No 2 Oktober 2017 yang mendorong terjadinya belajar itulah yang biasa disebut dengan motivasi belajar.Motivasi dipandang sebagai dorongan mental yang menggerakkan dan mengarahkan perilaku manusia, termasuk perilaku belajar.

Motivasi belajar sangat dibutuhkan dalam melakukan kegiatan belajar mengajar. Dengan adanya motivasi didalam diri siswa, maka siswa akan bersemangat untuk belajar.

Hal ini akan memberikan dampak yang positif terhadap nilai belajar siswa. Siswa yang memiliki motivasi kuat, akan mempunyai banyak energi dalam melakukan kegiatan belajar, sehingga prestasi belajar yang diperoleh akan lebih maksimal.

Motivasi belajar merupakan salah satu faktor yang mempengaruhi keberprestasian siswa dalam melakukan kegiatan belajarnya.Semakin tinggi motivasi dalam diri siswa tentunya berdampak pada efektifitas dan efesiensi belajarnya. Dan sebaliknya, kurangnya motivasi dalam diri siswa akan memberikan prestasi belajar yang kurang memuaskan.

Ekonomi merupakan pembelajaran yang menarik untuk dipelajari, didalamnya kita dapat mempelajari fakta-fakta yang telah terjadi dalam kehidupan sehari-hari.Namun kenyataannya, sebagian besar siswa menganggap ekonomi sebagai pelajaran yang sulit dan membosankan, sehingga siswa kurang bergairah untuk mempelajari ekonomi. Salah satu masalah dalam pembelajaran ekonomi di SMA adalah kurangnya keaktifan siswa ketika proses belajar mengajar berlangsung, siswa hanya menunggu sajian guru tanpa ada usaha untuk mencari dan menemukan sendiri pengetahuan, keterampilan dan sikap yang dibutuhkan pada kondisi ini disebabkan karena rendahnya motivasi dan minat belajar dalam diri siswa. Seiring dengan itu pembahasannya juga terhadap materi yang diajarkan akan berkurang dan pada akhirnya bermuara pada rendahnya prestasi belajar siswa.

Kurangnya motivasi yang dimiliki baik dari dalam diri siswa (intrinsik) 
maupun dari orang tua, teman ataupun guru (ekstrinsik) diakibatkan masih banyaknya waktu yang dipakai untuk bermain dan masih banyak waktu yang dipakai untuk membantu orang tua daripada belajar. Dimana di sekolah ini siswa merasa bosan dikarenakan pemberian motivasi yang monoton, dan motivasi yang sama berulang-ulang. Dengan demikian berpengaruh terhadap prestasi belajar siswa disekolah ini.

Dari hasil observasi yang penulis lakukan disekolah SMA Swasta Raksana Medan pada kelas XI IPS, sekitar 65\% dari 89 siswa memiliki motivasi yang rendah. Hal ini dapat dilihat dari kegiatan siswa-siswi di kelas. Dimana siswa tersebut kurang tekun dan ulet dalam mengerjakan tugas, kurangnya minat untuk mengajukan pertanyaan, mengemukakan tanggapan terhadap masalah yang diberikan, maupun mengembangkan gagasan orang lain. Siswa lebih senang menyontek dengan temannya, bahkan banyak yang tidak memperhatikan ketika guru menjelaskan.Siswa juga sering mengeluh jika guru memberikan tugas secara terus-menerus.Dengan begitu dapat dikatakan bahwa motivasi belajar siswa di sekolah ini masih dapat dkategorikan rendah. Hal ini berpengaruh terhadap aktivitas belajar, yang akan mengakibatkan pembelajaran tidak baik sehingga mempengaruhi prestasi belajar siswa.

Proses belajar mengajar akan lebih baik lagi apabila digabungkan dengan kepercayaan diri siswa. Dimana siswa yang tidak memiliki kepercayaan didalam dirinya maka akan sulit berkembang. Kemampuan ataupun bakat yang ada didalam dirinya tidak akan berkembang, melainkan akan menurun jika tidak diasa. Banyak siswa yang memiliki prestasi belajar yang rendah dikarena mereka tidak yakin dengan kemampuan yang mereka miliki.Padahal terkadang kemampuan yang mereka miliki lebih besar dibandingkan temannya yang memiliki prestasi belajar yang tinggi.

Untuk dapat mencapai kesuksesan dalam hidup kepercayaan diri sangatlah
JURNAL NIAGAWAN Vol 6 No 2 Oktober 2017 penting agar kita bisa memaksimalkan potensi yang ada didalam diri kita maupun didalam pergaulan. Percaya diri itu berasal dari diri sendiri, bagaimana tekat kita untuk melakukan hal yang kita inginkan dan butuhkan dalam menjalani proses kehidupan. Untuk dapat membentuk kepercayaan diri pada dasarnya berawal dari keyakinan diri kita sendiri, bagaimana kita mampu menghadapi segala tantangan dalam kehidupan, sehingga kita mampu berbuat sesuatu untuk menghadapi segala tantangan yang ada.

Banyak guru yang tidak menyadari hal itu.Mereka terkadang kurang peduli kepada siswa yang tidak aktif dikelas.Bahkan lebih peduli kepada siswa yang tergolong pintar.Tanpa disadari hal inilah yang mendorong siswa tidak memiliki kepercayaan didalam dirinya.Rasa percaya diri pada anak tidak tumbuh begitu saja tanpa bantuan dari luar.Kasih sayang ataupun perhatian dari guru berpengaruh pada rasa percaya diri siswa. Biasanya anak yang mendapatkan perhatian perkembangan kepercayaan dirinya akan baik. Siswa yang selalu diberi tugas dan kepercayaan juga rasa dirinya akan berkembang dengan baik.

Setelah mengadakan observasi di sekolah tersebut, 55\% dari 89 siswa/siswa di kelas XI IPS kepercayaan dirinya dapat dikatakan rendah. Hal itu terlihat dari kurangnya potensi belajar yang ada didalam diri siswa.Banyak siswa yang kurang aktif dalam menyampaikan pendapatnya sendiri didalam kelas, dan kurang memiliki rasa percaya diri pada saat memecahkan soal-soal pelajaran ekonomi yang dimiliki oleh guru, maupun mengerjakan tugas harian yang diberikan.Siswa cenderung pasif dan menunggu perintah dan intruksi dari guru.

Untuk itu penulis menganggap motivasi belajar dan kepercayaan diri siswa sangat penting dalam proses belajar mengajar. Dimana siswa yang memiliki motivasi yang tinggi namun dia kurang memiliki kepercayaan didalam dirinya maka tentu saja akan berdampak pada prestasi belajarnya. 
Motivasi dan kepercayaan diri sama-sama berperan penting dalam proses belajar siswa disekolah.

Rendahnya prestasi belajar seorang siswa dapat dilihat dari terlampauinya nilai kriteria ketuntasan minimal siswa sesuai yang telah ditetapkan oleh sekolah. Dimana rendahnya prestasi belajar yang diperoleh siswa akan menunjukkan rendahnya proses pembelajaran. Hal ini menjadi permasalahan yang terjadi di SMA Swasta Raksana Medan.Banyak diantara siswa yang tidak menunujukan minat ataupun semangat belajar khususnya pada mata pelajaran ekonomi.Hal ini ditunjukan masih banyaknya siswa yang tidak peduli terhadap penjelasan yang diberikan oleh guru, masih banyaknya siswa yang lebih memilih melamun atau berbicara dengan temannya daripada mendengarkan penjelasan guru.Hal ini tentu saja berpengaruh terhadap nilai ulangan ataupun nilai ujian siswa yang masih dibawah kriteria ketuntasan minimal.Disamping itu penulis kerap kali melihat siswa yang bersikap acuh tak acuh terhadap materi pembelajaran yang disampaikan oleh guru.

Melihat begitu pentingnya prestasi belajar dalam pendidikan, tentunya sekolah akan berusaha mengprestasikan siswa-siswi yang memiliki prestasi yang memuaskan didalam pelajaran. Akan tetapi pada kenyataannya, disekolah SMA Swasta Raksana Medan terjadi fenomena dimana masih ada juga siswa yang memperoleh nilai yang rendah pada mata pelajaran ekonomi.Rendahnya nilai siswa ini dapat dilihat dari beberapa siswa yang nilainya masih berada dibawah Kriteria Ketuntasan Minimum (KKM).Dimana Kriteria Ketuntasan Minimum (KKM) disekolah SMA Swasta Raksana Medan adalah sebesar 74.

\section{METODE PENELITIAN}

Jenis penelitian ini adalah penelitian expose facto. Penelitian ini dilaksanakan di SMA Swasta Raksana Medan yang beralamat
JURNAL NIAGAWAN Vol 6 No 2 Oktober 2017 di Jalan Gajah Mada No. 20 dan penelitian ini dilaksanakan pada semester Genap Tahun Ajaran 2015/2016. Populasi dalam penelitian ini adalah seluruh siswa kelas XI IPS di SMA Swasta Raksana Medan Tahun Ajaran 2015/2016 yang berjumlah 89 Siswa.Berdasarkan ketentuan tersebut maka sampel dalam penelitian ini ditetapkan sebanyak 89 orang.Uji instrumen menggunakan uji validitas dan reliabilitas angket.Uji asumsi klasik menggunakan uji normalitas dan uji lineraitas.Teknik analisa data dalam penelitian ini menggunakan analisis regresi berganda, uji hipotesis parsial (uji t), uji hipotesis simultan (uji f) dan koefisien determinasi $\left(\mathrm{R}^{2}\right)$.

\section{HASIL DAN PEMBAHASAN}

Berdasarkan hasil perhitungan hipotesis secara parsial menunjukkan bahwa untuk variabel motivasi belajar diperoleh thitung $=$ 2,151 dengan taraf signifikan 0,000. Karena thitung $=2,151>\mathrm{t}$ tabel 1,663 dan taraf signifikan yang diperoleh $0,034<0,05$. Hal ini membuktikan bahwa terdapat pengaruh yang positif dan signifikan dari motivasi belajar (X1) terhadap Prestasi belajar ekonomi siswa (Y) kelas XI IPS SMA Swasta Raksana Medan Tahun Ajaran 2015/2016, maka Ha diterima dan Ho ditolak. Sementara dari variabel lingkungan kepercayaan diri siswa t hitung= 3,337 dengan taraf signifikan 0,000 . Karena $t$ hitung=.3,337> $\mathrm{t}$ tabel 1,663 dan taraf signifikan yang diperoleh $0,001<0,05$, maka kepercayaan diri siswa (X2) dinyatakan berpengaruh secara positif dan signifikan terhadap variabel Prestasi belajar ekonomi siswa (Y) kelas XI IPS SMA Swasta Raksana Medan Tahun Ajaran 2015/2016, maka Ho ditolak dan Ha diterima.

Dari pengujian hipotesis secara simultan antara motivasi belajar dan kepercayaan diri siswa terhadap prestasi belajar siswa diketahui bahwa nilai $\mathrm{F}$ hitung adalah sebesar 21.783 sedangkan nilai $\mathrm{F}$ tabel 3,95 dengan taraf signifikansi $0,000<0,05$ 
maka dapat disimpulkan bahwa nilai $\mathrm{F}$ hitung $>\mathrm{F}$ tabel, yang berarti Ha diterima dan $\mathrm{H} 0$ ditolak bahwa variabel independen berpengaruh simultan dan signifikan terhadap variabel dependen. Artinya semakin tinggi motivasi belajar dan kepercayaan diri siswa maka prestasi belajar ekonomi siswa juga akan meningkat.

Berdasarkan hasil penelitian terbukti bahwa motivasi belajar dan kepercayaan diri siswasecara bersama-sama memberikan kontribusi sebesar $336 \quad(33,6 \%)$ terhadap prestasi belajar ekonomi siswa melalui pengujian koefisien determinasi $\left(\mathrm{R}^{2}\right)$, sedangkan sisanya sebesar $66,4 \%$ dipengaruhi oleh variabel lain yang tidak diteliti. Dari hasil penelitian ditemukan bahwa variabel yang paling berpengaruh adalah variabel X1.

\section{KESIMPULAN DAN SARAN}

Berdasarkan hasil pengujian dan pembahasan terhadap hasil penelitian yang telah dikumpulkan mengenai pengaruh motivasi belajar dan kepercayaan diri terhadap prestasi belajar siswa kelas XI IPS SMA Swasta Raksana Medan Tahun Pelajaran 2015/2016, diperolah beberapa kesimpulan sebagai berikut:

1. Hasil persamaan regresi linear berganda diperoleh $\mathrm{Y}=28.013+0,234 \quad \mathrm{X}_{1}+0,458 \quad \mathrm{X}_{2}$ pada persamaan regresi tersebut memiliki arti bahwa arah pengaruh motivasi belajar (X1) terhadap prestasi belajar IPS (Y) siswa kelas XI IPS SMA Swasta Raksana Medan Tahun Pelajaran 2015/2016bersifat positif. Artinya setiap terjadi peningkatan intensitas pemberian motivasi belajar maka akan diikuti dengan meningkatnya
JURNAL NIAGAWAN Vol 6 No 2 Oktober 2017 prestasi belajar IPS siswa kelas XI IPS SMA Swasta Raksana Medan Tahun Pelajaran 2015/2016. Hasil dari uji hipotesis secara parsial variable motivasi belajar dengan prestasi belajar dengan menggunakan uji-t menyatakan "Ada pengaruh positif dan signifikan variabel Motivasi belajar terhadap pretasi belajar siswa Kelas XI IPS SMA Swasta Raksana Medan Tahun Pelajaran 2015/2016."

2. Berdasarkan persamaan regresi berganda, arah pengaruh kepercayaan diri (X2) terhadap prestasi belajar (Y) siswa kelas XI IPS SMA Swasta Raksana Medan Tahun Pelajaran 215/2016, bersifat positif. Artinya setiap terjadi peningkatan intensitas kecerdasan emosional maka akan diikuti

dengan meningkatnya prestasi belajar siswa kelas XI IPS SMA Swasta Raksana Medan Tahun Pelajaran 2015/2016. Hasil uji hipotesis secara parsial (uji t) menyatakan bahwa "Ada pengaruh yang positif dan signifikan antara kepercayaan diri terhadap prestasi belajar ekonomi siswa kelas XI IPS SMA Swasta Raksana Medan Tahun Pelajaran 2015/2016.

3. Hasil pengujian hipotesis secara simultan terhadap variabel motivasi belajar, kepercayaan diri dan prestasi belajar dengan menggunakan uji $\mathrm{F}$ menunjukkan "Ada pengaruh positif dan signifikan antara pola asuh orang tua dan kecerdasan emosional secara bersama sama memeberikan kontibusi sebesar 0,336 atau $33 \%$ terhadap prestasi belajar siswa. 


\section{REFERENSI}

Abdurrahman, Mulyono. 2003. Pendidikan Bagi Anak Berkesulitan Belajar.Jakarta: Rineka Cipta.

Anamulyana.Pengertian Motivasi Belajar, hhtp://www.blogspot.com (21 April 2016)

Bengkulu, Ewintri. Faktor-Faktor Yang Mempengaruhi Kepercayaan Diri, http://www.blogspot.com (06 Maret 2016)

B, Hamzah. 2006.Teori Motivasi dan Pengukurannya. Jakarta: Bumi Aksara.

Dimyati.Mudjiono. 2006.Belajar dan Pembelajaran. Jakarta: Rineka Cipta.

Djamarah, Syaiful. 2008. Psikologi Belajar. Jakarta: Rineka Cipta.

Djiwandono, Sri Esti Wuryani. 2006. Psikologi Pendidikan. Jakarta: Grasindo.

Driscoll P, Marcy. Psychology Of Learning For Instruction.Florida State University.

Farhan, Abu. Pengertian Kepercayaan Diri, http://www.blogspot.com (21 April 2016)

Hamalik, Oemar. 2008. Kurikulum dan Pembelajaran. Jakarta: Bumi Aksara.

Hamdani, M,A. 2011. Strategi Belajar Mengajar.Bandung : Pustaka Setia.

Istarani dan Intan Pulungan. 2015. Ensklopedia Pendidikan. Jakarta : Media Persada.

Jananti, Nooriza.2013. Pengaruh Kepercayaan Diri, Budaya Lokal dan Pendidikan Agama Terhadap Hasil Belajar Mata Pelajaran Ekonomi Siswa Kelas XI IPS SMA Negeri 1 DEMAK Tahun Ajaran 2013/2014. ISSN 2252-6544

Kandoli, Loulisa.Motivasi dan Hubungannya Dengan Prestasi Belajar Mahasiswa Pada Mata Kuliah Tata Hidang di Jurusan PKK Fakultas Teknik Universitas Negeri Manado.ISSN 20873581.Vol. 2/no.2/september/2011.

Khodijah, Nyanyu. 2014. Psikologi Pendidikan. Jakarta: Rajagrafindo Persada.

Maydianasari, Lenna. Hubungan Konsep Diri Dengan Motivasi Belajar.ISSN 23386800. Vol.1/no.1/2013.

Miru, Alimuddin. 2009. Pengaruh Motivasi Belajar Terhadap Prestasi Belajar Mata Diklat Instalasi Listriks Siswa SMK Negeri 3 Makassar.Vol. 1/no.1/april/2009.Fakultas Teknik Universitas Negeri Makassar.
JURNAL NIAGAWAN Vol 6 No 2 Oktober 2017

Poniman, Farid dkk. 2008. Kubik Leadership.Gramedia Pustaka Umum: Jakarta.

Sadirman, AM. 2008. Interaksi dan Motivasi Belajar Mengajar. Jakarta: Rajagrafindo Persada.

---------------. 2011. Interaksi dan Motivasi Belajar Mengajar. Jakarta: Rajagrafindo Persada.

Sarastika, Pradipta. 2014. Buku Pintar tampil Percaya Diri. Yogyakarta:Araska. 